\begin{abstract}
Alina Walenia
University of Rzeszów, Faculty of Economics

e-mail: alinawalenia@poczta.onet.pl
\end{abstract}

\title{
Control Mechanisms in the Process of Preventing Corruption in Public Administration Offices on the Example of Entities in the Podkarpackie Province
}

\begin{abstract}
A crucial element of the mechanism to prevent corruption in public administration is the explicit procedure of reacting to corruption events, regardless of whether it is based on ISO procedures or if it results from another system of legal solutions. The statutory anti-corruption solutions introduced in public institutions in the form of management control involve the staff abiding by ethical values, and they serve to improve the transparency, legal conduct, and ethics in the operations of a public administration office. The results of empirical research confirm that the implemented management control procedures form integral parts of the anti-corruption system in public entities.
\end{abstract}

Keywords: control, corruption, public administration

JEL Classification: H70, M14

\section{Initial remarks}

In Poland, no model or generally binding principles of creating anti-corruption measures in public institutions have been created. There are no solutions which would set out corruption prevention standards throughout the public sector, or ones that would ensure the transparency of administrative activities and strengthen the ethical behaviour of the administrative staff. Each institution which decides to introduce anti-corruption policies selects the proper tools and methods of implementation independently. This results in fragmentation of anti-corruption policy in the 
public sector, ${ }^{1}$ as well as significant differences in the applied approaches and practices, starting with bureaucratic systems related to quality management, and ending with soft regulations of an ethical nature. Polish public institutions infrequently publish information about the effectiveness of the solutions applied - there are no publicly available audits or evaluation measures. Usually, only fragmentary information regarding the implemented codes of ethics, regulations issued, or the obtained ISO certificates is published. ${ }^{2}$

In the corruption prevention process in public administration offices, a particular role is played by system solutions regarding management control standards which are implemented based on the guidelines of the Minister of Finance. ${ }^{3}$ The cited guidelines indicate that anti-corruption measures in public administration offices require a multi-aspect approach, and the management control procedures which are in place, and the parameterisation of the principles of conduct are not sufficient. Efforts to strengthen attitudes and ethics awareness among staff are needed. Elements of an educational, organisational and technical nature, together with formal procedural solutions, improve the effectiveness of anti-corruption activities.

At every public institution there should be a specified system of anti-corruption solutions and regulations which would contribute to increasing the transparency, legality and ethical operation of the public administration office. The most important of the elements are codes of ethics and codes of ethical conduct, the activity of the ethics advisor, internal communication, and adequate training. In these documents, particular attention regarding anti-corruption should focus on:

(1) the transparency of operations of the public institution as well as the 'four eyes principle;'

(2) the principle of staff rotation in areas susceptible to corruption;

(3) the creation of a corruption prevention position (with tasks closely combining a part of the functions of the ethics advisor and a person responsible for the anti-corruption system at institutions).

The ethical principles aimed at corruption prevention were presented in the Regulation of the Council of Ministers on the guidelines for compliance with civil service principles and on the civil service principles of ethics. ${ }^{4}$ The document sets out six principles of ethics to be followed by civil servants. These include: the principle of decent conduct, the principle of civic services, the principle of loyalty, the principle of political neutrality, the principle of impartiality, and the principle of

\footnotetext{
${ }^{1}$ Anti-corruption Policy. Assessment of effectiveness of anti-corruption policy of the Polish governments implemented in the years 2001-2011, Stefan Batory Foundation's Programme for Combating Corruption, Warsaw 2011.

${ }^{2}$ E. Kowalczyk, Kontrola zarządcza w jednostce sektora finansów publicznych: wzory instrukcji i procedur [Management Control in a public finance sector entity: specimen instructions and procedures] Presscom, Poznań 2010.

${ }^{3}$ Announcement No. 23 of the Minister of Finance of 16 December 2009 on the standards of management control for the public finance sector (Official Journal of the Ministry of Finance No. 15, item 84).

${ }^{4}$ Regulation No. 70 of the Chairman of the Council of Ministers of 6 October 2011 on guidelines for compliance with civil service principles and on the civil service principles of ethics (Monitor Polski Official Journal of 2011 No. 93, item 953).
} 
diligence. The canons of values which determine the principles of conduct of a public administration officer are provided in the code of administrative procedure. ${ }^{5}$ To this end, an ethical officer should be impartial, which means that decisions must be taken in the name of the common good, neglecting any self-benefit or benefit to people or organisations linked to the officer. The officer must be objective, which means that decisions must be taken solely based on subject-matter criteria.

Currently, in central offices as well as provincial and local government administration offices, there is no information available regarding the effects of implementing anti-corruption systems, or records on the experiences of the particular institutions regarding the effectiveness of the measures applied. ${ }^{6}$

In the light of the aforementioned problem regarding the applied anti-corruption mechanisms in public offices, it is particularly important to show the importance of management control in the process of the legal operations of the public sector.

The purpose of this publication is to present an assessment of, and comments regarding, the importance of the management control system in the process of preventing corruption in public administration offices, based on the results of empirical research. An opinion poll, in the form of a questionnaire, was carried out in 2014 on a group of 30 randomly selected public administration offices in the Podkarpackie Province. The questions referred to the selection of the identified areas relating to the management control systems in operation in public administration offices.

\section{Definition of corruption in public administration}

Corruption is undoubtedly one of the crimes that demoralise societies the most, as it threatens the sense of legality of the operations of state authorities, as well as the security of citizens. The phenomenon has dire consequences in the form of income lost by the state and illegitimate expenditures from the state budget. Corruption is often related to other forms of offences, specifically organised crime or business offences, including money laundering or tax fraud. The doctrine ${ }^{7}$ assumes that the difficulty in combating corruption is related to the thin line between legal and illegal actions, close relations between corrupt individuals, clandestine methods of operation, and masking manipulation techniques. The main reasons of corruption in public administration include:

\footnotetext{
${ }^{5}$ The Act of 14 June 1960 - Code of Administrative Procedure ("Journal of Laws" 1960, No. 30, item 168).

${ }^{6} \mathrm{~K}$. Puchacz, Nowe standardy kontroli zarzadczej w jednostkach sektora finansów publicznych: omówienie i propozycje wzorcowych rozwiąań [New standards of management control at public finance sector entities: discussion and proposals for model solutions], Ośrodek Doradztwa i Doskonalenia Kadr Publishing Press, Warsaw 2010.

${ }^{7}$ W. Sielaff, Bruchstellen im polizeilichen Berufsethos, Kriminalistik, 1992, No. 6, p. 352 [in:] Korupcja jako plaga społeczna XXI wieku [Corruption as a social plague of the $21^{\text {st }}$ century], red. B. Hołyst, "Przegląd Antykorupcyjny" 2011, No. 1, p. 26.
} 
(1) the lack of basic ethical values and ethics among officers;

(2) ease in gaining 'big' money from public funds;

(3) striving to achieve a high position in public or business life;

(4) competitive strain in the form of corrupt manipulations;

(5) absence of internal supervision and control.

Hołyst ${ }^{8}$ deems that the public areas in which corruption has intensified in recent years include the public administration system, including healthcare, national insurance, banks and the administration of state-owned companies and local government structures. The main corrupt activities of public administration authorities include the failure to disclose any irregularities detected, the exclusion of certain people and actions from control, the disclosure of information obtained during control to unauthorised parties, as well as the informal provision of administrative services.

According to the World Bank, 'corruption is the abuse of a public office or function for private gains.' In accordance with Article 2 of the Civil Law Convention on Corruption passed in Strasbourg on 4 November 1999,9 'corruption means requesting, offering, giving or accepting, directly or indirectly, a bribe or any other undue advantage or prospect thereof, which distorts the proper performance of any duty or behaviour required of the recipient of the bribe, the undue advantage or the prospect thereof.' The UNDP ${ }^{10}$ assumes that corruption is 'the misuse of public power, office or authority for private benefit - through bribery, extortion, influence peddling, nepotism, fraud, speed money or embezzlement.' Transparency International ${ }^{11}$ defines corruption as 'the abuse of entrusted power for private gain.'

In Poland, the definition of corruption is provided in the Act on the Central Anti-Corruption Bureau ${ }^{12}$. In accordance with Article 1.3a of the Act, corruption is an act:

(1) consisting in the promising, offering or giving by any person, directly or indirectly, any undue benefits to a public officer, personally for that offer or for any other person, in exchange for an action or omission within performing said function;

(2) consisting in the demand or acceptance by a public officer, directly or indirectly, of any undue benefits personally for that officer or for another person, or accepting a proposal or promise of such benefits, in exchange for an action or omission within performing said function;

(3) committed within a business, which comprises the performance of duties towards a public authority (institution), consisting in the promising, offering or giving, directly or indirectly, by a person managing an entity from

\footnotetext{
${ }^{8}$ B. Hołyst, op. cit., p. 27.

${ }^{9}$ Government Statement of 18 August 2004 on the binding force of the Civil Law Convention on Corruption passed in Strasbourg on 4 November 1999 ("Journal of Laws" 2004, 16 November).

${ }^{10}$ UNDP - United Nations Development Programme (Corruption and Development).

${ }^{11}$ Transparency International is an international, independent and non-government organisation that monitors, publicises and fights corruption practices, mainly in public life. It was established by Peter Eigen in 1993.

12 The Act of 9 June 2006 on the Central Anti-Corruption Bureau ("Journal of Laws" 2006, No. 104, item 708).
} 
outside of the public finance sector or otherwise working for the entity, of any undue benefits or accepting an offer or promise of such benefits, personally for that person or any other person, in exchange for an action or omission, which is a breach of such a person's duties and represents a socially harmful exchange.

In the quality systems implemented in public administration offices, corruption was defined as an action or omission, as well as the prospect of such conduct, for the purpose of gaining undue benefits, as given, promised or alleged, both material and immaterial, directly or indirectly. The definition of corruption covers all participants of the actual or potential exchange. A benefit may be material (in kind or in cash) or personal (promotion, giving a job). The Polish law expressed in the Act of 13 June 2003 on the Amendment of the Penal Code and some other Acts ${ }^{13}$ differentiates the following forms of corruption:

(1) passive and active bribery,

(2) paid protection,

(3) abuse of power,

(4) abuse of authority.

The provisions of the cited Penal Code explain the public function. Article 115.19 states that a person fulfilling a public function is a civil servant, member of local government authorities, or person employed by an organisational entity disposing of public funds, unless such activities are performed solely as a service, as well as another person whose rights and duties as regards public activity are determined or accepted by an act or an international agreement binding for the Republic of Poland. The definition of a person fulfilling a public function is much broader than that of a civil servant. It means an extension of the scope of corrupt actions, both active and passive. The aforesaid definition covers not only bribery but also many other corruption phenomena, related to corruption or similar to corruption in their nature, which should be prevented in an entity through the management control system.

\section{Management control in the process of preventing corruption in public finance sector entities}

The implementation of management control principles is a system solution of modern public policy, which is broadly applied in the financial planning system of the European Union and developed European countries. Changes introduced in the public finance system aim to ensure the effective use of public funds and result from the recommendations of international organisations referring to the transparency of public finances. ${ }^{14}$

\footnotetext{
${ }^{13}$ The Act of 13 June 2003 on the Amendment of the Penal Code ("Journal of Laws" 2005 No. 8, item 60 , as amended).

${ }^{14}$ OECD Best Practices for Budget Transparency, OECD, Paris 2001 [in:] Zmiany w systemie finansów publicznych niezbędne dla sprawnej realizacji Narodowego Planu Rozwoju na lata 2007-2013 [Changes
} 
In public administration offices, a formalised approach to quality management is not widespread. A system-based, institutional implementation of anti-corruption measures is neither required in a public office nor imposed by government programmes or institutions. ${ }^{15}$ System-based supervision over the quality of operations of public institutions is required by Articles 68 and 69 of the Act on Public Finance ${ }^{16}$, which impose the necessity of ensuring effective management control, understood to be all actions undertaken to ensure the performance of tasks and objectives in accordance with the law, and in an efficient, cost-effective and timely manner. The purpose of management control in reference to public institutions is to ensure:

(1) operations' compliance with legal regulations and internal procedures,

(2) effective and efficient operations,

(3) the reliability of reports,

(4) the protection of resources,

(5) compliance with and promotion of ethical conduct principles,

(6) the effective and efficient flow of information,

(7) risk management.

Proper management control, particularly in larger offices, requires highly bureaucratic solutions. Some of the offices have implemented the ISO system, trying to ensure the compliance of their operations with the Act on Public Finance ${ }^{17}$. In the guidelines of the Minister of Finance regarding the standards of management control for the public finance sector, one of the conditions of a proper internal environment of a public sector entity is that its staff abide by ethical values and there is proper ethical leadership. The document states that "managers and staff should be aware of the ethical values accepted by the entity and abide by the same when performing the tasks entrusted to them. The managers should support and promote abiding by the ethical values, giving a good example with their daily conduct and decisions made." Reference to the principles of ethics and the necessity of monitoring threats (mentioned further in that document in Chapter B 'Objectives and Risk Management') contribute to the proper performance of the objectives and tasks of public entities. In accordance with the guidelines, risk assessment must be carried out at least once a year. ${ }^{18}$

\footnotetext{
in the system of public finance as needed for effective performance of the National Development Plan for the years 2007-2013, ed. W. Misiąg, Expert Opinion, April 2005.

${ }^{15} \mathrm{P}$. Walentynowicz, Nowy rodzaj kontroli - kontrola zarzadcza w jednostkach sektora finansów publicznych [New type of control - management control at public finance sector entities], "Poradnik Rachunkowości Budżetowej” 2010, No. 8, p. 44.

${ }^{16}$ The Act of 27 August 2009 on Public Finance ("Journal of Laws" 2009, No. 157, item 1240).

${ }^{17}$ E.W. Babuśka, Zarzadzanie ryzykiem jako cel kontroli finansów publicznych [Risk management as an objective of public finance control], "Zeszyty Naukowe Uniwersytetu Ekonomicznego w Krakowie" 2013, No. 919, pp. 5-18.

${ }^{18}$ K. Winiarska, M. Postuła, Kontrola zarzadcza w systemie kontroli finansów publicznych [Management control in the system of public finance control] [in:] Kontrola zarzadcza w jednostkach sektora finansów publicznych [Management control at public finance sector entities], ed. K. Winiarska, Oficyna a Wolters Kluwer business, Warsaw 2012, pp. 42-45.
} 
Management control, understood to be a dynamic and integral process, must be continuously adjusted to the changes in the organisation. As defined by INTOSAI (International Organisation of Supreme Audit Institutions), internal control is a managing tool used make sure, to a reasonable degree, that the management objectives have been achieved. In accordance with the INTOSAI Guidelines for Internal Control Standards for the Public Sector, 'internal control is an integral process that is effected by an entity's management and personnel and is designed to address risks and to provide reasonable assurance that in pursuit of the entity's mission, the following general objectives are being achieved:

(1) executing orderly, ethical, economical, efficient and effective operations;

(2) fulfilling accountability obligations;

(3) complying with applicable laws and regulations;

(4) safeguarding resources against loss, misuse and damage'.

In order to ensure the proper performance of objectives and tasks of a public finance sector entity, which means being efficient, economical, timely and compliant with laws, various actions must be accepted, all of which make up the management control (Article 68 of the aforementioned Act on Public Finance). In accordance with the provisions of Article 69.1 of the Act on Public Finance, management control in the public finance sector should operate on two levels. The basic level of management control, which functions within the whole of the public finance sector, is a public finance sector entity ( $1^{\text {st }}$ level of management control). Within an entity, the manager is responsible for the functioning of management control. Moreover, within government administration, management control at the level of a government administration department ( $2^{\text {nd }}$ level of management control) should be implemented. The minister managing the respective government administration department is responsible for the functioning of the management control at that level. For the performance of management control tasks, the following control standards, specified in the aforementioned Announcement of the Minister of Finance, are crucial: organisational structure, determination of objectives and tasks, monitoring and assessment of their performance, current information.

\section{Assessment of the effectiveness of the implemented anti-cor- ruption mechanisms in the researched public finance sector en- tities in the Podkarpackie Province}

The opinion poll results ${ }^{19}$ (Fig. 1) show that the management control standards referred to in the aforementioned Announcement of the Minister of Finance comprise the organisational solutions implemented in public finance sector entities to a limited extent (20\% of responses). In the majority of entities $(70 \%)$, the internal regulations for management control procedures were prepared without any relationship

\footnotetext{
${ }^{19}$ The opinion poll was carried out in 2014 within a group of 30 randomly selected public administration offices in the Podkarpackie Province.
} 
to risk, so they rarely focus on achieving the objectives of operations, or on the prevention, detection and correction of irregularities. According to the responses of the public finance sector entities which were researched, only half of them perform self-assessment of the management control, and what dominates is a high self-assessment of the management of particular elements, i.e. the internal environment, objectives and risk management, control mechanisms, information and communication as well as monitoring and evaluation. Risk related to the activities carried out has been assessed at a limited number of entities (20\%).

Figure 1. Assessment of the management control systems implemented at public finance sector entities (\% of responses).
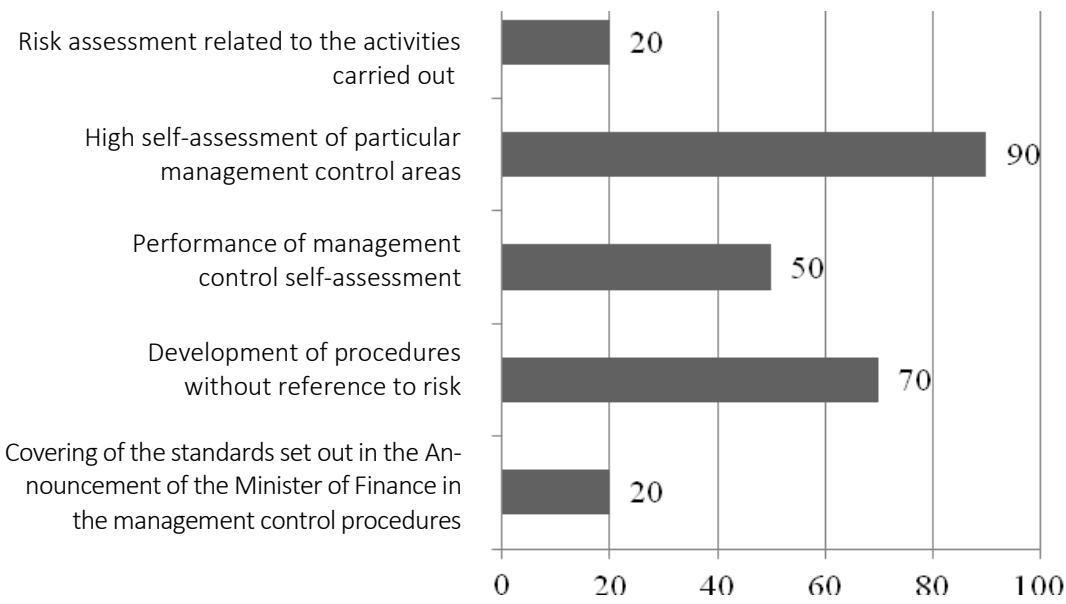

Source: Opinion poll results.

The opinion poll (Fig. 2) shows that in the majority of entities (75\% of responses) the management control procedures represent anti-corruption mechanisms and prevent the incorrect management of public funds, thus, they significantly affect the effectiveness and efficiency of reaching the objectives and performing tasks at the entity. The remaining respondents $(25 \%)$ said management control had no influence on the correct process of spending public funds, indicating that the control system is incorporated into the structure of the entity, and the tasks in that area have been stipulated for the particular staff members who deal with public spending.

At each of the researched public finance sector entities, control procedures are in the form of regulations set down by the entity manager. However, at only $20 \%$ of entities do these procedures cover the management control standards set out in the Announcement of the Minister of Finance for the public sector. At $90 \%$ of the researched public finance sector entities, management control procedures have been developed without any reference to risk, although periodical evaluation of compliance with the set out procedures has been performed. 
Figure 2. Assessment of the importance of management control in the system of anti-corruption mechanisms for the proper functioning of selected public finance sector entities (\% of responses).
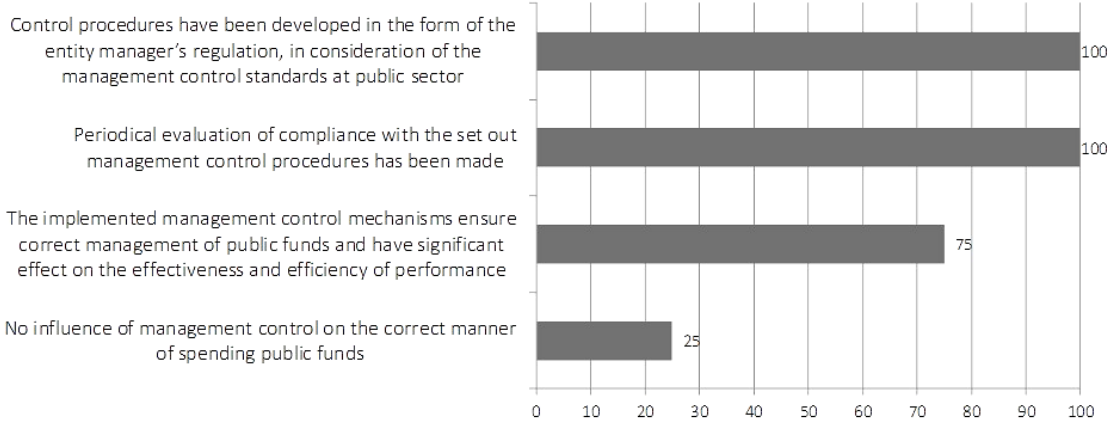

Source: Opinion poll results.

The opinion poll results show that in a majority of the public sector entities (70\% of responses), anti-corruption mechanisms aimed at ensuring the transparent and honest operations of public administration are limited to ethical regulations (Fig. 3). Activities in that regard refer mainly to improving staff awareness and imparting knowledge during the training provided. Anti-corruption education, which comprises abiding by the ethical principles, is widespread in government administration entities, but is significantly less frequent in local administration entities. The majority of the researched institutions $(80 \%)$ declared that their staff participated in training devoted to corruption hazards. They included both internal courses and training at central level.

The codes of ethics or codes of ethical conduct are binding in $20 \%$ of the researched institutions. However, in these institutions, information regarding the actual effectiveness of the code of ethics in administration was missing. There was no information regarding the results of anti-corruption measures either. In that scope, a lot depends on the attitude of the manager of the public entity and on combing the binding ethical regulations with other regulations regarding the office operations.

An extremely important role in the ethical infrastructure of an office is played by an ethics advisor. At the researched institutions, such a position of public trust was rarely present (10\%). The personal traits, character or bearing of the ethics advisor should contribute to building social relations, resolving conflicts, and making a diligent assessment of compliance with ethical standards. An important task of the ethics advisor is to carry out explanatory proceedings in the case of any possible breaches of ethical standards or the principles of abiding by internal procedures. Half of the researched public institutions indicated that the role of the management control system is the most important in creating anti-corruption mechanisms. 
Figure 3. Types of anti-corruption measures implemented by the researched public finance sector entities (\% of responses).

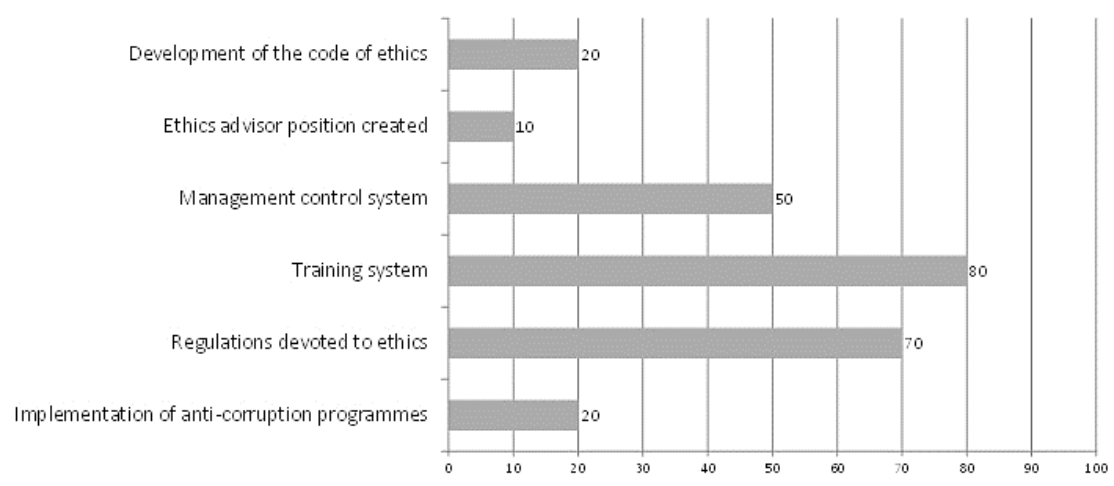

Source: Opinion poll results.

\section{Conclusions}

Management control in Polish public administration reflects a good and sufficient level of implementation, which means that it may contribute to effective anti-corruption prevention. The opinion poll results confirm that control procedures are designed particularly for anti-corruption activities and form an effective mechanism for liming threats in that regard. A majority of the researched public institutions in the Podkarpackie Province have implemented anti-corruption solutions limited solely to ethics principles, specifically regarding the improvement of staff awareness and knowledge within the training provided. It is another approach to preventing corruption and ensuring the transparency and integrity of public administration activities. Among the anti-corruption mechanisms in public administration offices, a major role is played by the ethical education of staff, which has a significant effect on the proper operations of public administration.

\section{References}

Anti-corruption Policy. Assessment of effectiveness of anti-corruption policy of the Polish governments implemented in the years 2001-2011, Stefan Batory Foundation's Programme for Combating Corruption, Warsaw 2011.

Babuśka E.W., Zarządzanie ryzykiem jako cel kontroli finansów publicznych [Risk management as an objective of public finance control], "Zeszyty Naukowe Uniwersytetu Ekonomicznego w Krakowie" 2013, No. 919. 
Bugdol M., Zarządzanie jakościa w urzędach administracji publicznej. Teoria i praktyka [Quality management at public administration offices. Theory and practice], Difin, Warsaw 2008.

Hołyst B., Korupcja jako plaga spoleczna XXI wieku [Corruption as a social plague of the $21^{\text {st }}$ century], "Przegląd Antykorupcyjny" 2011, No. 1.

Kowalczyk E., Kontrola zarządcza w jednostce sektora finansów publicznych: wzory instrukcji i procedur [Management Control in a public finance sector entity: specimen instructions and procedures], Presscom, Poznań 2010.

Puchacz K., Nowe standardy kontroli zarządczej w jednostkach sektora finansów publicznych: omówienie i propozycje wzorcowych rozwiazań [New standards of management control at public finance sector entities: discussion and proposals for model solutions], Ośrodek Doradztwa i Doskonalenia Kadr Publishing Press, Warsaw 2010.

Sielaff W., Bruchstellen im polizeilichen Berufsethos, Kriminalistik, 1992, No. 6, p. 352 [after:] Hołyst B., Korupcja jako plaga społeczna XXI wieku [Corruption as a social plague of the $21^{\text {st }}$ century], "Przegląd Antykorupcyjny" 2011, No. 1.

Walentynowicz P., Nowy rodzaj kontroli - kontrola zarzadcza w jednostkach sektora finansów publicznych [New type of control - management control at public finance sector entities], "Poradnik Rachunkowości Budżetowej" 2010, No. 8.

Winiarska K., M. Postuła, Kontrola zarządcza w systemie kontroli finansów publicznych [Management control in the system of public finance control] [in:] Kontrola zarzadcza w jednostkach sektora finansów publicznych [Management control at public finance sector entities], ed. K. Winiarska, Oficyna a Wolters Kluwer business, Warsaw 2012.

\section{Legal acts}

Announcement No. 23 of the Minister of Finance of 16 December 2009 on the standards of management control for the public finance sector ("Official Journal of the Ministry of Finance" 2009, No. 15, item 84).

The Act of 27 August 2009 on Public Finance ("Journal of Laws" 2009 No. 157, item 1240).

The Act of 13 June 2003 on Amendment of the Penal Code ("Journal of Laws" 2005 No. 8, item 60 , as amended).

The Act of 9 June 2006 on the Central Anti-Corruption Bureau ("Journal of Laws" 2006 No. 104, item 708).

The Act of 14 June 1960 - Code of Administrative Procedure ("Journal of Laws" 1960 No. 30, item 168).

Regulation No. 70 of the Chairman of the Council of Ministers of 6 October 2011 on guidelines for compliance with civil service principles and on the civil service principles of ethics ("Monitor Polski" 2011 No. 93, item 953). 